\title{
Evaluation of Quantitative and Qualitative Traits of Forage Sorghum and Lima Bean under Different Nitrogen Fertilizer Regimes in Additive - Replacement Series
}

\author{
Zandvakili Omid Reza (Corresponding author) \\ Agronomy, Abouraihan Campus, University of Tehran, Iran \\ E-mail: omid.zandvakili@yahoo.com \\ Iraj Allahdadi \\ Agronomy and Plant Breeding Department \\ Abouraihan Campus, University of Tehran, Iran \\ Dariush Mazaheri \\ Agronomy and Plant Breeding Department \\ College of Agriculture and Natural Resources University of Tehran, Iran \\ Gholam Abbas Akbari \\ Agronomy and Plant Breeding Department \\ Abouraihan Campus, University of Tehran, Iran \\ Emad Jahanzad \\ Department of Plant, Soil and Insect Science \\ University of Massachusetts, Amherst, USA \\ Mohammad Mirshekari \\ Agronomy, Abouraihan Campus, University of Tehran, Iran
}

Received: November 14, 2011 Accepted: December 1, $2011 \quad$ Online Published: May 7, 2012

doi:10.5539/jas.v4n6p223

URL: http://dx.doi.org/10.5539/jas.v4n6p223

\begin{abstract}
In order to study the effect of intercropping on forage yield of Sorghum and yield components of lima bean at different planting proportions and nitrogen fertilizer levels, an experiment was conducted at the research farm of University of Tehran in the year of 2009. Quantitative attributes such as dry weights of sorghum, yield and yield component of lima bean were measured in two sampling during growth season. The highest fresh and dry weight of sorghum fodder belonged to additive proportions of sorghum. Nitrogen application treatments had significant effect on sorghum total dry matter of fodder $\left(160\right.$ urea Kgha $\left.^{-1}\right)$ and total yield of lima bean ( 80 urea Kgha $\left.^{-1}\right)$ seed. Evaluation of Land Equivalent Ratio (LER) indicated that the highest LER obtained in the combination of $100 \%$ sorghum and $20 \%$ lima bean which indicates the advantage of intercropping (LER=1.26).
\end{abstract}

Keywords: Intercropping, Additive series, Replacement series, Land equivalent ratio

\section{Introduction}

Researchers put emphasis on the relation between biodiversity and sustainability inasmuch as a marginal increase in diversity will enhance the complexity and productivity of ecosystem (Burel and Baudry, 1995; 
Mclauhglin and Mineau, 1995). Effective utilization of resources and improving crop Productivity makes intercropping to play an important role in agriculture (Yang et al, 1999). Inter and intra-specific competition determines the degree of resource complementarily, however the availability of environmental resources and the relative frequency of the species and the density of components inevitably influence competition (Hauggaard, Andersen, Jørnsgaard and Jensen, 2006). Yield advantage occurs when inter-specific competition is less than intra-specific competition in other mean the components of intercrop compete only partly for the same growth resources (Vandermeer, 1992; Willey, 1985). Intercropping cereal and legumes is a practice in which the $\mathrm{N}$ fixed by the latter enhances the qualitative and quantitative traits of the former to finally reaching food security and sustainability (Swaminathan, 1998). The efficiency of such cropping systems is expressed as land equivalent ratio (LER) in which the application of different levels of nitrogen fertilizers affects its increasing, decreasing and unchanging trend (Ghanbari and Lee, 2003). Just as providing enough nitrogen optimizes the yield potential, disregarding proper management like applying excessive amount of $\mathrm{N}$ fertilizer proves disagreeable outcome, so determining proper nitrogen fertilizer rate in order to produce more forage and to reduce environmental hazard must be taken into consideration (Jaynes, Colvin, Karlen, Cambardella, \& Meek, 2001). Production of forage sorghum with applying little amount of $\mathrm{N}$ fertilizer is manageable, but this crop displays a great deal of reaction in response to applied nitrogen (Ram and Sing, 2001). Considering soil fertility, weather conditions and the species, the rate of consumption for $\mathrm{N}$ fertilizer by farmers varies from 45 to $224 \mathrm{kgha}^{-1}$ (Zhao, Kakani and Reddy, 2005). Forage sorghum displayed a positive reaction to increasing nitrogen to about $200 \mathrm{kgha}^{-1}$ but further application had no effect on yield increase (Gupta and Sing, 1988). Although sorghum utilizes nitrogen more efficiently than corn and is more resistant to drought and higher temperatures (Young and Long, 2000) but inadequacy of $\mathrm{N}$ fertilizer reduces congregation of dry matter and leads to growth reduction (Zhao et al, 2005). The legume typically suffers competition from the cereal which results in lower yield in intercropping compared with sole-cropping moreover addition of $\mathrm{N}$ fertilizer may impede the growth due to greater competition from increased cereal growth. (Searle et al., 1981; Ofori and Stern, 1986; Rao, Rego and Willey, 1987). Replacement series are intercrop patterns in which the total density is kept constant although the proportion of each species varies proper to its recommended sole-cropping and in additive series the species are grown in a way that the overall density exceeds $100 \%$ which induces the most productive intercrops (Fukai and Trenbath, 1993). Lima bean can be grown in a wide range of ecological conditions from warm temperate zones as well as arid and semi arid tropical regions. Intercropping lima bean with maize or sorghum and its sole-cropping is common in Africa (Bejiga and Brink, 2006). Utilizing forage sorghum is being practiced recently in many parts in Iran although corn has almost always been the option for most dairies but marked downward trend in water resources forces agronomists for a proper substitute, therefore in order to improve nutritive value and high efficiency to utilize resources, intercropping with legumes is introduced in a complementary system in that such systems are being recognized to increase productivity and resource use efficiency in a high input agriculture (Burel and Baudry, 1995). Considering qualitative traits, maize and cowpea intercrops gave higher total forage dry matter digestibility than maize or cowpea sole crops and led to increased forage quality (crude protein and dry matter digestibility concentration) than maize monoculture and higher water-soluble carbohydrate concentrations than sole cowpea (Dahmardeh, Ghanbari, Syasar and Ramrodi, 2009). Intercropping maize and soybean resulted to a higher crude protein content compared with maize sole cropping (Toniolo, Sattin and Mosca, 1987). Intercropping beans with wheat enhanced forage dry matter compared with bean sole crop and also enhanced crude protein, neutral detergent fibre content, and water-soluble carbohydrates compared with beans and wheat sole crops (Ghanbari-Bonjar and Lee, 2002; Lithourgidis and Dordas, 2010). The crude protein yield, dry matter yield, and ash content of maize forage increased by intercropping legumes compared with maize monoculture (Javanmard, Nasab, Javanshir, Moghaddam and Janmohammadi, 2009). The objective of the present study were to evaluate forage intercropping advantage and intercrop competition under different levels of $\mathrm{N}$ soil availability to examine how nitrogen response of each yield component affects the productivity of the system as a whole.

\section{Materials and Methods}

The experiment was conducted in the Agricultural Research Centre, University of Tehran, Abourahan,

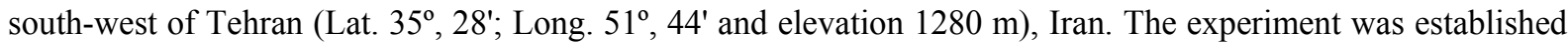
in a silt loam soil with PH 7.1. Seed bed preparation included ploughing, disk harrowing, and cultivation. Sowing was performed manually by planting tree times more seeds than the expected plant densities. The design was in randomized complete block design in split plot arrangement with four replications. The main plots consisted of four levels of nitrogen fertilizer as $\left(\mathrm{N}_{0}: 0, \mathrm{~N}_{1}: 80, \mathrm{~N}_{2}: 160\right.$ and $\mathrm{N}_{3}: 240$ urea Kg ha $\left.{ }^{-1}\right)$ and sub plots including seven different planting proportions as pure stands of sorghum (SSSS) and lima bean (BBBB), replacement series as $75 \%$ Sorghum $+25 \%$ bean (SSSB), $50 \%$ Sorghum $+50 \%$ bean (SBSB), $25 \%$ sorghum $+75 \%$ bean (SBBB) and additive series as $100 \%$ sorghum $+10 \%$ bean (SB10\%) and $100 \%$ sorghum $+20 \%$ bean 
(SB20\%). Plots were fertilized with the same amount of fertilizer as $60 \mathrm{kgha}^{-1} \mathrm{p}_{2} \mathrm{O}_{5}$ and $60 \mathrm{kgha}^{-1} \mathrm{k}_{2} \mathrm{O}$ but N fertilizer was added once before planting and then two thirds of it at the fourth leaf stage of forage sorghum. The row spacing for sorghum was $0.75 \mathrm{~m}$ and the beans $0.5 \mathrm{~m}$ in both sole-cropping and intercropping plots. Sorghum and bean were sown to a depth of 5 and $4 \mathrm{~cm}$ respectively by hand in 20 may 2009 . About three weeks after first irrigation rows were thinned to the required experimental density. Hoeing was performed mainly in two stages when the height of the plants reached 10 and $20 \mathrm{~cm}$ and then because of shading the competition capability of weeds reduced significantly. Forage sorghum was harvested in two cuts. First cut was performed in 4 august 2009 after the height of the plant was almost $1.5 \mathrm{~m}$. In order to keep subsistence and the continuation of the growth, sorghum was harvested from $10 \mathrm{~cm}$ above the soil surface (Slatter and Stuart, 1995). Fresh weight of the samples were measured at site straight away then the samples were put in the oven at $70 \mathrm{C}$ for $48 \mathrm{~h}$ and weighed to record dry matter yield. The second cut of sorghum was done as the same trend for the first cut with simultaneous harvest for bean. In order to determine yield component of lima bean after randomly selecting 10 plants from each plot and transferring to the laboratory the number of pods, seeds per pod and 100 seed weigh was measured. The analysis of variance of the data was carried out, using SAS software. Treatment mean differences were separated by the Duncan Multiple Range Test (DMRT) at probability level of 0.05 .

The efficiency of intercropping system can be evaluated by the land equivalent ratio (LER) defined as the total area required under sole-cropping to produce the equivalent yields obtained under intercropping.

$\mathrm{LER}=\mathrm{Ls}+\mathrm{Lb}=(\mathrm{Ys} / \mathrm{Ss})+(\mathrm{Yb} / \mathrm{Sb})$

Where $\mathrm{Ss}$ and $\mathrm{Sb}$ are sole crop yields of the component crop sorghum and bean, and $\mathrm{Ys}$ and $\mathrm{Yb}$ are the yields of component sorghum and bean in the intercrop. A total LER value greater than 1.0 indicates advantages from intercropping in terms of the use of environmental resources for plant growth. Value Ls and Lb greater than 0.5 indicate advantage for an individual species in intercropping system over the sole cropping.

\section{Result and Discussion}

\subsection{Forage Fresh Matter of Sorghum}

The result revealed that the effect of planting pattern for fresh weight was significant (Table 2). The highest amount of yield for fresh weight obtained in additive series $(100 \% \mathrm{~S}: 20 \% \mathrm{~B})$ in which with the reduction of sorghum in replacement patterns the yield of fresh weight decreased and resulted to the lowest amount of yield in $(25 \% \mathrm{~S}: 75 \% \mathrm{~B})$. Nitrogen levels didn't have any significant effect on fresh weight of sorghum. Result for per plant considering fresh weight indicated a significant effect, in that with the increase in proportion of lima bean the yield of forage sorghum increased as well.

\subsection{Forage Dry Matter of Sorghum}

\subsubsection{Nitrogen Efficacy}

Increasing nitrogen to the level of $160 \mathrm{~kg}$ per hectare resulted to the increase in yield for forage dry weight of sorghum although there was no significant difference between the two treatments of 160 and $240 \mathrm{~kg}$ nitrogen per hectare. There are various reports considering the positive effects of nitrogen fertilizer on yield increase. The majority of the surveys reported yield increase proper to increasing nitrogen even though the best possible treatment or nitrogen level is highly dependent on the characteristics of soil, climate and the experimental place. (Coaldrake, 1985) and (Bebawi, 1989) reported that with increasing nitrogen levels in forage sorghum and millet the number of tillers and the leaf area of plants increases and this ultimately leads to a rise in dry matter. (Zhao et al, 2005) reported that different amount of nitrogen fertilizer with affecting the height and the leaf area resulted in significant difference between treatment. On low-N soils, the non-legume is often suppressed, but on high-N soils the vigorous growth of the non-legume usually causes it to dominate over the legume by shading (Trenbath, 1976).

\subsubsection{Planting Patterns Effectuality}

Lowering the proportion of sorghum in intercropping resulted to the reduction of yield therefore the combination of $25 \% \mathrm{~S}: 75 \% \mathrm{~B}$ with $3905.32 \mathrm{~kg} \cdot \mathrm{ha}^{-1}$ ranked the lowest (Table 3). It should be taken into consideration that this lower amount of yield is due to reduction of sorghums proportion in intercropping and even though the number of plants in this pattern is 1.4 of the sole cropping but the amount of yield will not follow this proportion (Figure 1). Total biomass yield of intercropped maize per unit area tended to increase with increasing maize population (Luiz and Willey, 2008). Greater resource use by intercrops was considered as the biological basis for obtaining yield advantages (Willey, 1979; Keating and Carberry, 1993). The morphological and physiological differences among intercrop components result in their ability to occupy different niches. Thus, environmental resources could be more efficiently utilized and converted to biomass by mixed stands of crops than by pure stands. 


\subsubsection{Orthogonal Contrasts}

There is a quadratic relationship comprised of the linear and quadratic trends (Table 4). The highly significant $\mathrm{F}$ value for this linear trend implies that any increase in fertilizer $\mathrm{N}$ will increase the yield in that the slope is positive. The linear response in nitrogen uptake to fertilizer nitrogen indicates that luxury levels of nitrogen had not been reached by the plants (Comudum, 1981), In addition the significance of quadratic effect implies that beside an increasing trend there is a quadratic trend between yield and fertilizer and increasing yield for each amount of $\mathrm{N}$ fertilizer is not stable and it starts to slow down from the $160 \mathrm{~kg}^{\mathrm{g}} \cdot \mathrm{ha}^{-1}$ level. There was no significant cubic contrast however.

\subsection{Yield Components of Lima bean}

\subsubsection{Lima Bean Grain Yield}

Nitrogen fertilizer and planting patterns had significant effect on the yield of lima bean (Table 5), in that increasing nitrogen to the level of $80 \mathrm{~kg} \cdot \mathrm{ha}^{-1}$ increased the yield of seed per hectare but more input of nitrogen not only didn't affect the yield but also there was significant decrease of yield in comparison with control treatment. Such results from a legume which obtains its nitrogen from biological fixation with bacteria is expectable and it seems that the increase of seed yield at level of $80 \mathrm{~kg} \cdot \mathrm{ha}^{-1}$ is the result of nitrogen performance to act as a starter and reduction of seed yield at the level of $240 \mathrm{~kg}^{-\mathrm{ha}^{-1}}$ nitrogen is most likely due to its effect to prevent the function of bacteria to fix nitrogen, besides the competition for growth resources caused lima bean to be overcomed by sorghum. On high regimen of nitrogen, the process of fixation by legumes reduces and in these conditions the non-legume species has more dominance and completion for limiting source (Hiebsch and Mc collum, 1987). The utilization of different nitrogen levels in intercropping bean with corn resulted to the yield reduction of legume with increasing nitrogen fertilizer (Weilray and Mcfadden, 1991).

Mean comparison for different levels of planting patterns indicated that increasing forage sorghum in row proportion lead to significant reduction in seed yield of lima bean (Figure 2) in which the sole cropping of lima bean with $1866.66 \mathrm{~kg} \cdot \mathrm{ha}^{-1}$ ranked the highest and in contrast the additive series had the lowest amount of yield (Table 6). Intercropping corn and soybean under different planting pattern and nitrogen fertilizer revealed that seed yield of soybean was the highest compared with intercropped patterns in which the competition for resources highly affected yield and yield components (Panhwar et al, 2004). The results by (Ntare, Williams and Bationo, 1993) showed that the legume is suppressed when intercropped with a $\mathrm{c}_{4} \mathrm{crop}$. Grain yield per unit area of intercropped beans decreased as maize population increased (Mutungamiri, Mariga and Chivinge, 2001).

\subsubsection{Number of Pods per Plant}

Number of pods per plant was the yield component most responsible for the yield. Increasing nitrogen to 80 $\mathrm{kg} \cdot \mathrm{ha}^{-1}$ increased the number of pods of lima bean although there was no significant effect between the application of $\mathrm{N}_{2}$ and $\mathrm{N}_{3}$ levels, besides by reducing the proportion of lima bean in intercropping patterns the number of pods per plant decreased as well. The highest number of pods obtained in sole cropping as though additive series were ranked as the lowest (Table 6). When nitrogen increased from 0 to $30 \mathrm{~kg} \cdot \mathrm{ha}^{-1}$ the number of pods per plant increased from plant population of M1 to M2 (Morgado and Willey, 2008). The number of pods per plant is the most sensitive component of yield and the most important attribute to determine yield of bean (Rezends and Ramalhol, 1994; Scarisbrick, Wilkes and Kempsor, 1977). In intercropping soybean and sorghum the fewer number of pods per plant and the fewer number of seeds per pod was responsible for decreased yield of soybean (Elmore and Jackobs, 1984).

\subsubsection{Number of Seeds per Pod}

Result showed that the effect of row proportion was significant $(p<0.01)$ in that the highest number of seed per pod obtained in sole-cropping of lima bean (Table 5) and it has a very high correlation with beans yield (Jindal and Guptal, 1984). On the other hand it is reported that the number of seed per pod is less in intercropped plants in comparison with sole-cropping although this difference is not statistically significant. (Oforti and Stern, 1987; Tsubo and Walker, 2001).

\subsubsection{Lima Bean 1000 Seed Weight}

Increasing sorghum lead to the reduction of weight of 100 seeds in that the additive series had the lowest amount for this trait. Significant difference between sorghum and soybean in various planting patterns considering weight of seed is reported (Lesoing and Francis, 1999). The positive relation between beans seed yield with increasing its proportion in intercropping on one side and decreasing its yield with increasing sorghums proportion on the other side is due to sorghums shading on the shorter species which resulted in decreased yield (Parves, Gardner, \& Boote 1989). 


\subsection{Land Equivalent Ratio (LER)}

The yield advantages of intercropping treatments relative to sole-cropping are indicated by total LER values (Table 7). With no nitrogen applied the sorghum LER in intercropping was about the unity. The decrease below unity might have been the result of some competition from the beans even though at this level of nitrogen the intercropped sorghum produced as much yield as sole-cropping and that any competition from the beans could have been slight. Total LER tended to increase with increasing nitrogen to the level of N2. LER values were greater than one in almost all intercropping systems with different planting ratios which indicated yield advantage of intercropping over sole cropping of sorghum (Figure 3, 4, 5). The highest LER obtained by sowing the crops in additive designs in ratio of $(100 \% \mathrm{~S}+20 \% \mathrm{~L})$ it is apparent that by maintaining the proportion of sorghum at $100 \%$ in intercropping, sorghums yield are less affected by bean competition than when sorghum proportion is lowered in replacement designs. Bean LER increased with increasing bean population (Luiz and Willey, 2008). This might be attributed to the fact that bean plants possibly benefited from the nitrogen applied though this trend started to decrease for highest level of applied nitrogen. Reducing bean density to $25 \%$ gave a higher sorghum LER and a corresponding decrease in beans LER inasmuch as the lowest bean LER obtained in ratio of $75 \% \mathrm{~S}+25 \% \mathrm{~B}$. The result indicated that intercropping of Forage sorghum and Lima bean gave higher land use efficiency than sole cropping of sorghum.

\subsection{Forage Quality}

\subsubsection{Protein Content}

With increasing nitrogen fertilizer the protein content increased as well however there was no significant effect between the two levels of $\mathrm{N}_{2}$ and $\mathrm{N}_{3}$ (Table 8). The contribution of nitrogen on accumulation of $\mathrm{CP}$ and higher forage quality roots in its vital rule in formation of aminoacids (Buxton, Mertens and Fisher, 1996). Mean comparison $t$ showed that the highest amount of protein content obtained in row proportion of $25 \% \mathrm{~S}+75 \% \mathrm{~B}$ with $18.8 \%$ and the least amount went to the pure stand of forage sorghum with $14.88 \%$ (Table 9). (Sood and Sharma, 1992; Sistachs and Sing, 1991) reported that intercropping sorghum and legume lead to the increase in forage protein content. In comparison with sole cropping intercropping corn and soybean resulted into an increase of about $8 \%$ to $17 \%$ (Herbert et al, 1984). Row proportion of intercropping components inevitably affects the crude protein content of forage. Comparing different planting patterns in intercropping maize fodder and cowpea revealed that row proportion affected the content of CP in various ratios in which increasing cowpea in proportion resulted to the increase of protein content (Ibrahim, Rafq and Sultan, 2006). The present study confirmed the results previously stated by others in that increasing lima bean in proportion lead to an increase in $\mathrm{CP}$ of forage sorghum and the yield of both crops was maintained at the highest however it was noticeable that in additive series despite having the lowest yield for legume, the cp content of sorghum was considerable.

\subsubsection{Water Soluble Carbohydrates (WSC)}

The highest amount of WSC went to the pure stand of sorghum alongside with additive series and the least amount went to replacement series as in the proportion of $25 \% \mathrm{~S}: 75 \% \mathrm{~B}$ with $13.10 \%$ (Table 8 ). On the whole increasing sorghums proportion in the mixture resulted to a higher WSC. In an experiment conducted by (Dahmarde et al, 2009) maximum WSC was recorded in sole-cropping of intercropped maize and bean. (Homayooni, Mazaheri, Majnoon and Jahansooz, 2004) reported that in evaluation of intercropping sorghum and soybean, increasing the ratio of sorghum resulted to the significant enhancement of carbohydrates. The higher WSC content of sole-cropping in maize $(126 \mathrm{~g} / \mathrm{kg} \mathrm{DM})$ was reported by (Ngongoni et al, 2007) compared with other intercropped combinations (84-89 $\mathrm{g} / \mathrm{kg} \mathrm{DM})$. Nitrogen fertilizer levels didn't have any significant effect on this trait

\subsubsection{Acid Detergent Fiber (ADF)}

The highest amount of ADF belonged to the sole-cropping of forage sorghum with $36.60 \%$ and the least amount obtained in the proportion of $25 \% \mathrm{~s}: 75 \% \mathrm{~B}$ with $32.17 \%$. (Table 8 ). In evaluation of strip intercropping of legumes and grasses the percentage of acid detergent fiber in grass increased significantly with its increasing in row proportion (Roos et al, 2004). In an experiment of forage sorghum-legume mixture in high plains of USA The ADF concentration was not different between monoculture BMR100 and BMR100-legume mixtures, but differences did occured between monoculture PS210BMR and forage sorghum mixed with either cowpea, soybean, or tepary bean, When averaged over these three legume treatments, sorghum forage-legume mixtures were lower in ADF concentration than monoculture (Contreras et al, 2009). Reduction in ADF concentration of forage sorghum can be attributed to increasing of grain to whole biomass ratio (Dahmarde et al, 2009). Similar results have been reported by others working with sorghum-soybean and maize (Esmail et al, 1991). 


\subsubsection{Dry Matter Digestibility (DMD)}

DMD was significantly affected by row proportion. The intercrop pattern of $50 \% \mathrm{~S}: 50 \% \mathrm{~B}$ with $57.42 \%$ produced the highest DMD and the pure stand of sorghum produced the lowest DMD. Intercropping a $\mathrm{C}_{4}$ crop like sorghum with legumes increased the dry matter digestibility of forage sorghum significantly (Sood and Sharma, 1992). Nitrogen levels didn't affect DMD significantly.

\subsubsection{Crude Fiber (CF)}

Row proportions had significant effect on CF (Table 8), while N fertilizer didn't affect CF, significantly and the highest amount of $\mathrm{CF}$ obtained in the pure stand of forage sorghum with $41.22 \%$ and the lowest amount achieved in the proportion of $25 \% \mathrm{~S}: 75 \% \mathrm{~B}$ with $35.77 \%$. Significant result were obtained in vicia sativa as well as cowpeas along with grass by intercropping. The $\mathrm{CF}$ of grass decreased while that of legumes increased due to intercropping. Intercropping and combination of intercropping and fertilizer improved forage quality by decreasing crude fiber of grass (Muhammad AU, 2010).

\subsubsection{ASH}

The ash content was affected by different planting patterns at $(\mathrm{p}<0.01)$. The replacement series produced the lowest amount of ash content and the highest percentage of it obtained in pure stand of sorghum followed by additive series. Traits like crude protein and ash content of forage maize increased when intercopped with legumes compared to its sole-cropping (Javanmard et al, 2009). The results are contradictory to those of (Ayub et al, 2004). These contradictory results might have been due to differences in legume species or variation in soil fertility status.

\section{Conclusions}

The study conducted revealed that in additive series yield of forage sorghum increased to a significant level which ranked higher than sole-cropping and other row proportions, besides intercropping resulted in higher sorghum forage quantity, because of more $\mathrm{N}$ supply for sorghum, induced by complementary interaction between forage sorghum and lima bean in intercropping for $\mathrm{N}$ consumption. In order to have a higher dry matter yield the rate, time and application of $\mathrm{N}$ fertilizer should be taken into consideration so that without disturbing the biological function of legumes the objectives can be achieved.

\section{Acknowledgement}

This research was supported by a grant from Department of Agronomy and Plant Breeding, University of Tehran. The authors are grateful to Dr. Allahdadi and Prof. Mazaheri for providing many valuable comments.

\section{References}

Ayub, M., Tanveer, A., Nadeem, M. A., \& Shah, S. M. A. (2004). Study on the fodder yield and quality of sorghum grown alone and in mixture with rice bean. Pak. J. Life Soc. Sci., 2(1), 46-48.

Bebawi, F. (1989). Forage sorghum production on a witchweed infected soil in relation to cutting height and nitrogen. Agronomy Journal, 78, 827-832.

Beets, W. C. (1977). Multiple cropping of maize and soybean. Neth. J. Agric. Sci., 25, 95-102.

Bejiga, G., \& Brink, M. (2006). Cereals and Pulses. Plant Resources of Tropical Africa. Wageningen, Netherlands: PROTA Foundation/Backhuys Publishers/CTA. p. 91.

Burel, F., \& Baudry, J. (1995). Species biodiversity in changing agricultural landscapes: A case study in the Pays d,Auge, France. Agriculture, Ecosystems and Environment, 55, 193-200. http://dx.doi.org/10.1016/0167-8809(95)00614-X

Buxton, D. R., Mertens, D., \& Fisher, D. S. (1996). Forage quality and ruminant utilization In Cool-season forage grasses. pp. 229-266.

Coaldrake, P. (1985). Leaf area accumulation of pearl millet as affected by nitrogen supply. Field Crops Research, 11, 185-192. http://dx.doi.org/10.1016/0378-4290(85)90101-7

Comudum, Y. (1981). Effect of maize + legume intercropping systems and fertilizer nitrogen on crop yields and residual nitrogen. Field Crops Research, 133-145.

Contreras, F. E., Lauriault, L. M., Marsalis, M., Angadi, S., \& Puppala, N. (2009). Performance of forage sorghum-legume mixtures in southern High Plains, USA. Online. Forage and Grazing lands. http://dx.doi.org/10.1094/FG-2009-0401-01-RS 
Dahmardeh, M., Ghanbari, A., Syasar, B., \& Ramrodi, M. (2009). Intercropping maize and cow pea as whole-crop forage. Journal of Food, Agriculture and Environment, 7, 505-509.

Duli Zhao, K., Gopal Kakani, V., \& Reddy, R. (2005). Nitrogen deficiency effects on plant growth, leaf photosynthesis, and reflectance properties of sorghum. European Journal of Agronomy, 22, $391-403$. http://dx.doi.org/10.1016/j.eja.2004.06.005

Elmore, R. W., \& Jackobs, J. A. (1984). Yield and yield components of sorghum and soybean of varying plant $\begin{array}{lllll}\text { heights } \quad \text { when } & \text { Agron. } & \text { 5., } & 761-564 .\end{array}$ http://dx.doi.org/10.2134/agronj1984.00021962007600040012x

Esmail, S. H., Bolsen, M., \& Pfaff, L. (1991). Maturity effects on chemical composition, silage fermentation and digestibility of whole plant grain sorghum and soybean silages fed to beef cattle. Animal Feed Science and Technology, 33, 79-85. http://dx.doi.org/10.1016/0377-8401(91)90047-V

Fukai, S., \& Trenbath, B. R. (1993). Processes determining intercrop productivity and yields of component crops. Field Crops Res., 34, 247-271. http://dx.doi.org/10.1016/0378-4290(93)90117-6

Ghanbari, B. A., \& Lee, H. C. (2003). Intercropped wheat (Triticum aestivum.) and bean (Vicic faba.) as a whole crop forage: Effect of harvest time on forage yield and quality. Grass Forage. Sci, 27, 535-539.

Gupta, M. L., \& Singh, R. M. (1988). Effect of intercropping of legumes in sorghum at different levels of nitrogen under rainfed condition on sorghum equivalent and monetary return. Indian Journal of Agriculture Science, 58, 25-20.

Hauggaard, N., Andersen, H., Jørnsgaard, M. K., \& Jensen, E. S. (2006). Competitive dynamics in two- and three-component intercrops. Field Crops Research, 95, 256-267.

Herbert, S., Putnam, D. H., Poosfloyd, M. H, Vargas, A., \& Creighton, J. F. (1984). Forage yield of intercropping corn and soybean in various planting patterns. Agron. J., 76, 507-510. http://dx.doi.org/10.2134/agronj1984.00021962007600040001x

Hiebsch, C. K., \& McCollum, R. E. (1987). Area $\times$ Time Equivalency Ratio: A method for evaluatting the productivity of intercrops. Agron.J., 79, 15-22. http://dx.doi.org/10.2134/agronj1987.00021962007900010004x

Homayooni, H., Mazaheri, D., Majnoon Hosseini, N., \& Jahansooz, M. R. (2004). Evaluation of Sorghum-legume intercropping under different intercropping systems. Eighth congress of crop production and plant breeding. University of Giulan.

Ibrahim, M., Rafq, M., \& Sultan, A. (2006). Green fodder yield and quality evaluation of maize and cow pea sown alone and in combination. Journal of Agricultural Research, 44(1), 15-21.

Javanmard, A., Nasab, A. D. M., Javanshir, A., Moghaddam, M., \& Janmohammadi, H. (2009). Forage yield and quality in intercropping of maize with different legumes as double cropped. J Food Agr Environ, 7, $163-166$.

Jaynes, D. B., Colvin, T. S., Karlen, D. L., Cambardella, C. A., \& Meek, D. W. (2001). Nitrate loss in subsurface drainage as affected by nitrogen fertilizer rate. Journal of Environment, 30, 1305-1314, http://dx.doi.org/10.2134/jeq2001.3041305x

Jindal, S. K., \& Gupta, B. S. (1984). Component analysis of yield in cowpea. Indian J. Agric. Sci., 54, $183-185$.

Lesoing, G. W., \& Francis, C. A. (1999). Strip intercropping effect on yield and yield components of corn, grain sorghum and soybean. Agronomy Journal, 91, 807-813. http://dx.doi.org/10.2134/agronj1999.915807x

Lesoing, G. W., \& Francis, C. A. (1990). Strip cropping of corn and soybean under dry land and irrigated conditions. p.150. Ag. Abstract 1990. ASA, Madison, WI. Papendick, R.I., D. A.

Lithourgidis, A. S., \& Dordas, C. A. (2010). Forage yield, growth rate, and nitrogen uptake of faba bean intercrops with wheat, barley, and rye in three seeding ratios. Crop Sci., 50, 2148-2158. http://dx.doi.org/10.2135/cropsci2009.12.0735

Luiz, B. M., \& Robert, W. W. (2008). Sci. Agric. (Piracicaba, Braz.), 65(5), 474-480.

Luiz, B. M., \& Willey, R. W. (2008). Optimum plant population for maize-bean intercropping system in the Brazilian semi-arid region. Sci. Agric., 65, 474-480.

Muhammad, A. U. (2010). Forage production in Panicum grass-legumes intercropping by combining geometrical configuration, inoculation and fertilizer under rainfed conditions kassel university press, ISBN: 978-3-89958-890-3. 
McLaughlin, A., \& Mineau, P. (1995). The impact of agricultural practices on biodiversity. Agriculture, Ecosystems and Environment, 55, 201-212. http://dx.doi.org/10.1016/0167-8809(95)00609-V

Mutungamiri, A., Mariga, I. K., \& Chivinge, A. O. (2001). Evaluation of maize (Zea mays L.) cultivars and density for dryland maize- bean intercropping. Tropical Agriculture, 78, 8-12.

Ntare, B. R., Williams, J. H., \& Bationo, A. (1993). Physiological determinants of cowpea seed yield effected by phosphorus fertilizer and sowing data intercrop with millet. Field-Crops- Research, 53(3), 151-158, http://dx.doi.org/10.1016/0378-4290(93)90149-H

Ngongoni, N. T., Mwale, M., Mapiye, C., Moyo, M. T., Hamudikuwanda, H., \& Titterton, M. (2007). Evaluation of cereal-legume intercropped forages for smallholder dairy production in Zimbabwe. Livestock Research for Rural Development, 19,126-134.

Oforti, F., \& Stern, W. R. (1987). Relative sowing time and density of component crops in maize/cowpea intercrop system. Expl. Agric., 23, 42-52. http://dx.doi.org/10.1016/0378-4290(86)90062-6

Ofori, F., \& Stem, W. R. (1986). Maize/cowpea intercrop system Effect of nitrogen fertilizer on productivity and efficiency. Field Crops Res., 14, 247-261.

Panhwar, A., Hussain, M., Fida, K., Mumtaz, A., \& Muhammad, S. (2004). Performance of Maze In Intercropping System With Soybean Under Different Planting Patterns And Nitrogen Levels. Journal of applied science, 4(2), 201-204.

Parves, A. Q., Gardner, F. Q., \& Boote, K. J. (1989). Determinate and indeterminate type soybean cultivar responses to pattern, density and planting date. Crop Sci., 29, 150-157.

Ram, S. N., \& Sing, B. (2001). Effect of nitrogen and harvesting time on yield and quality of sorghum (Sorghum bicolor) intercropped with legumes. Indian Journal of Agronomy, 46, 32-37.

Rao, M. R., Rego, T. J., \& Willey, R. W. (1987). Response of cereals to nitrogen in sole cropping and intercropping with different legumes. Plant Soil, 101, 167-177. http://dx.doi.org/10.1007/BF02370641

Rezends, G. D., \& Ramalho, M. A. (1994). Competitive ability of maize and common bean (Phaseolus vulgaris) cultivars intercropped in different environments. J. Agric. Sci. Camb., 123, 185-190, http://dx.doi.org/10.1017/S0021859600068441

Roos, S. M., King, J. R., Donavan, J. T. O., \& Paner, D. S. (2004). Intercropping berseem clover with barley and oat cultivars for forage. Agron. J., 96, 1719-1729. http://dx.doi.org/10.2134/agronj2004.1719

Searle, P. G. E., Yothapong, C., Shedden, D. C., \& Nance, R. A. (1981). Effect of maize and legume intercropping systems and fertilizer nitrogen on crop yields and residual nitrogen. Field Crops Res., 4, 133-145. http://dx.doi.org/10.1016/0378-4290(81)90063-0

Scarisbrick, D. H., Wilkes, D. M., \& Kempsor, R. (1977). The effect of varying plant population density on the seed yield of navy bean (Phaseolus vulgaris) in south-east England. J. Agric. Sci. Camb., 88, 567-577. http://dx.doi.org/10.1017/S0021859600037242

Sistachs, M., \& Sing, L. (1991). Intercropping of forage sorghum, maze and soybean during establishment of different grasses in amontmorillonitic soil II. Guinea grass (Panicum maxicum., Cuban Journal of Agricultural science, 25(1), 83-87.

Slatter, J., \& Stuart, P. (1995). Nutrifeed description, agronomy and management. Forage Agronomy Notes. Pacific Seeds., Queensland, Australia.

Sood, B. R., \& Sharma, V. K. (1992). Effect of nitrogen level on the yield and quality of forage sorghum intercropping with legumes. Indian Journal of Agronomy, 37(4), 642-644.

Swaminathan, M. S. (1998). Crop production and sustainable food security. In Chopra, V. L., Singh, R. B. and Verma, A. (eds). Crop Productivity and Sustainability-Shaping the Future. Proceedings of the Second International Crop Science Congress, New Delhi, India. pp. 3-18.

Toniolo, L., Sattin, M., \& Mosca, G. (1987). Soyabean-maize intercropping for forage. Eurosoya, 5, 73-78.

Trenbath, B. R. (1976). Plant interactions in mixed crop communities. In Papendick, R. I., Sanchez, P.A., Triplett, G. B. (Eds), Multiple Cropping, vol. 27. American Society of Agronomy, pp. 129-169 (special publication).

Tsubo, M. S., \& Walker, E. (2001). Comparisons of radiation use efficiency of mono/intercropping system with different row orientation. Field Crop. Res., 71, 17-29. http://dx.doi.org/10.1016/S0378-4290(01)00142-3 
Vandermeer, J. (1992). The Ecology of intercropping Cambridge University Press.

WeilRay, R., \& McFadden, M. E. (1991). Fertility and weed stress effects on performance of maize / soybean intercrop. Agron. J., 83,717-721. http://dx.doi.org/10.2134/agronj1991.00021962008300040014x

Willey, R. (1985). Evaluation and presentation of intercropping advantages. Exp. Agr., 21, 119-33. http://dx.doi.org/10.1017/S0014479700012400

Willey, R. (1979). Intercropping: its importance and research needs. Part П. Agronomy and research approaches Field Crops Research, 32, 1-10.

Yang, L. I., Zhang, F. S., \& Christie, P. (1999). Interspecific complementary and competitive interaction between intercropped maize and faba bean. Plant Soil, 212, 105-114. http://dx.doi.org/10.1023/A:1004656205144

Young, K., \& Long, S. P. (2000). Crop Ecosystem Responses to Climatic Change: Maize and Sorghum. CABI Publishing, Wallingford, 107-131.

Table 1. Meteorological parameters during the growing seasons

\begin{tabular}{llllll}
\hline \multirow{2}{*}{ Months } & \multicolumn{2}{l}{ Temperature ${ }^{\circ} \mathrm{C}$} & \multirow{2}{*}{ Rainfall mm } & \multirow{2}{*}{ Relative Humidity \% } \\
\cline { 2 - 4 } & $\min$ & $\max$ & mean & 3.3 & 49 \\
\hline April & 6.6 & 20.1 & 13.3 & 2 & 46 \\
May & 13.2 & 26.5 & 19.8 & .5 & 33 \\
June & 16.5 & 34.2 & 26.3 & 0 & 28 \\
July & 22.3 & 38.3 & 30.3 & .2 & 35 \\
August & 21.5 & 39.8 & 30.6 & 6.4 & 40 \\
September & 16.7 & 34 & 25.4 & & \\
\hline
\end{tabular}

Table 2. ANOVA based on randomized complete block design (RCBD) for fresh and dry matter yield and yield in each plant of Sorghum

\begin{tabular}{|c|c|c|c|c|c|c|c|c|}
\hline & \multicolumn{4}{|c|}{$1^{\text {st }}$ harvest } & \multicolumn{3}{|c|}{$2^{\text {nd }}$ harvest } & \multirow[b]{2}{*}{ DW.per plant } \\
\hline & Fresh weight & FW.per plant & Dry weight & DW. per plant & Fresh weight & FW. Per plant & Dry weight & \\
\hline Block & 413603082 & 10737.15 & 1131753.31 & 82.74 & 592967882 & 15745.48 & 4363332.71 & 358.86 \\
\hline Factor(A) & $58821832^{\text {n.s }}$ & $653.81^{\mathrm{n} . \mathrm{s}}$ & $11389140.35^{* *}$ & $610.04^{* *}$ & $6287326^{\text {n.s }}$ & $862.15^{\text {n.s }}$ & $14255739.81^{* *}$ & $1184.05^{* *}$ \\
\hline Error(a) & 84560258 & 9381.59 & 333122.25 & 31.02 & 92699363 & 7365.85 & 73497.62 & 14.62 \\
\hline Factor(B) & $3414785026^{* *}$ & $38176.87^{* *}$ & $158426533.92^{* *}$ & $980.70^{* *}$ & $00415104^{* *}$ & $114083.54^{* *}$ & $150986246.0^{* *}$ & $651.17^{* *}$ \\
\hline$A^{*} B$ & $40667665^{\mathrm{n} . \mathrm{s}}$ & $27.97^{\mathrm{n} . \mathrm{s}}$ & $75515.72^{\mathrm{n} . \mathrm{s}}$ & $15.93^{\mathrm{n} . \mathrm{s}}$ & $50537326^{\text {n.s }}$ & $414.65^{\mathrm{n} . \mathrm{s}}$ & $43459.71^{\mathrm{n} . \mathrm{s}}$ & $80.50^{\mathrm{n} . \mathrm{s}}$ \\
\hline Error(b) & 76822005 & 364.65 & 261515.52 & 26.30 & 67495660 & 657.43 & 379882.03 & 39.37 \\
\hline total & 24471577474 & 831790.62 & 846517356.58 & 9078.34 & 4441944896 & 732198.95 & 834888739.42 & 1586.47 \\
\hline
\end{tabular}


Table 3. Duncan's mean comparison test results for fresh and dry matter yield and yield in each plant of Sorghum

\begin{tabular}{|c|c|c|c|c|c|c|c|c|}
\hline & \multicolumn{3}{|c|}{$1^{\text {st }}$ harvest } & \multicolumn{5}{|c|}{$2^{\text {nd }}$ harvest } \\
\hline & $\begin{array}{l}\text { Fresh } \\
\text { weight }\end{array}$ & $\begin{array}{l}\text { FW.per } \\
\text { plant }\end{array}$ & $\begin{array}{l}\text { Dry } \\
\text { weight }\end{array}$ & $\begin{array}{l}\text { DW.per } \\
\text { plant }\end{array}$ & $\begin{array}{l}\text { Fresh } \\
\text { weight }\end{array}$ & $\begin{array}{l}\text { FW.per } \\
\text { plant }\end{array}$ & $\begin{array}{l}\text { Dry } \\
\text { weight }\end{array}$ & $\begin{array}{l}\text { DW.per } \\
\text { plant }\end{array}$ \\
\hline SSSS & $68313 b c$ & $343.125 f$ & $10763.82 b$ & $53.81 \mathrm{e}$ & $65250 \mathrm{bc}$ & $294.37 \mathrm{e}$ & $9980.11 \mathrm{c}$ & $50.94 c$ \\
\hline SSSB & $66266 c$ & $470 c$ & $9378.63 c$ & $62.88 \mathrm{c}$ & $60031 \mathrm{c}$ & $419.35 b$ & $8514.22 \mathrm{~d}$ & $57.39 b$ \\
\hline SBSB & $53156 d$ & $545 b$ & $6994.12 \mathrm{~d}$ & $68.74 b$ & $49438 d$ & $492.52 \mathrm{a}$ & $6504.42 \mathrm{e}$ & $64.29 \mathrm{a}$ \\
\hline SBBB & $40531 \mathrm{e}$ & $578.75 a$ & $3905.32 \mathrm{e}$ & $75.72 \mathrm{a}$ & $35563 \mathrm{e}$ & $501.87 \mathrm{a}$ & $3437.5 f$ & $68.12 \mathrm{a}$ \\
\hline SB10\% & $73625 b$ & $383.125 \mathrm{e}$ & $11771.22 \mathrm{a}$ & $58.88 \mathrm{~d}$ & $70750 \mathrm{ab}$ & $366.25 \mathrm{~d}$ & $11034.62 b$ & $54.29 b c$ \\
\hline SB20\% & $80813 a$ & $411.875 \mathrm{~d}$ & $11948.13 \mathrm{a}$ & $59.73 d c$ & $74625 a$ & $382.14 c$ & $11521.13 \mathrm{a}$ & $57.28 b$ \\
\hline
\end{tabular}

Means of each group in columns of each treatment with similar letters are not significantly different.

Table 4. Orthogonal contrast to evaluate response surface

\begin{tabular}{|c|c|c|c|}
\hline Contrast & $\mathrm{df}$ & Mean square & F value \\
\hline linear & 1 & 421733917.9 & $1557.02 * *$ \\
\hline quadratic & 1 & 11607529.8 & $42.85^{* *}$ \\
\hline cubic & 1 & 69698.5 & $0.26^{\mathrm{n} . \mathrm{s}}$ \\
\hline
\end{tabular}

Table 5. ANOVA based on randomized complete block design (RCBD) for yield and yield component of Lima bean

\begin{tabular}{lllllll}
\hline & df & $\begin{array}{l}\text { Yield per } \\
\text { hectare }\end{array}$ & $\begin{array}{l}\text { Yield per } \\
\text { plant }\end{array}$ & $\begin{array}{l}\text { Number of pods per } \\
\text { plant }\end{array}$ & $\begin{array}{l}\text { Number of seed } \\
\text { per pod }\end{array}$ & $\begin{array}{l}\text { Weight of 100 } \\
\text { seed }\end{array}$ \\
\hline Block & 3 & 94280.11 & 11.054 & 12.41 & 0.9702 & 212.50 \\
Factor(A) & 3 & $166015.69^{* *}$ & $20.91^{* *}$ & $23.06^{*}$ & $0.0325^{\text {n.s }}$ & $48.61^{\text {n.s }}$ \\
Error(a) & 9 & 6830.99 & 1.06 & 10.19 & 0.3438 & 271.75 \\
Factor(B) & 5 & $7616160.52^{* *}$ & $124.37^{* *}$ & $288.84^{* *}$ & $10.46^{* *}$ & $1766.66^{* *}$ \\
A*B & 15 & $9672.58^{\text {n.s }}$ & $0.676^{\text {n.s }}$ & $4.80^{\text {n.s }}$ & $0.3688^{\text {n.s }}$ & $41.11^{\text {n.s }}$ \\
Error(b) & 60 & 6640.79 & 0.74 & 6.49 & 0.531 & 110.27 \\
total & 95 & 39466807.94 & 784.94 & 2104.04 & 95.84 & 19295.84 \\
\hline
\end{tabular}

${ }^{* *} \mathrm{p}<0.01 ;{ }^{*} \mathrm{p}<0.05 ;{ }^{\mathrm{n}}$ : non significant

Table 6. Duncan's mean comparison test results for yield and yield component of Lima bean

\begin{tabular}{lllll}
\hline & Yield per hectare & Number of pods per plant & Number of seed per pod & weight \\
\hline BBBB & $1866.86 \mathrm{a}$ & $15.668 \mathrm{a}$ & $5.662 \mathrm{a}$ & $308.75 \mathrm{a}$ \\
SBBB & $1207.07 \mathrm{~b}$ & $14.756 \mathrm{a}$ & $5.593 \mathrm{a}$ & $302.50 \mathrm{ab}$ \\
SBSB & $709.02 \mathrm{c}$ & $12.637 \mathrm{~b}$ & $5 \mathrm{~b}$ & $295.51 \mathrm{~b}$ \\
SSSB & $349.68 \mathrm{~d}$ & $12.218 \mathrm{~b}$ & $4.543 \mathrm{~b}$ & $286.87 \mathrm{c}$ \\
SB10\% & $133.87 \mathrm{e}$ & $6.643 \mathrm{c}$ & $3.868 \mathrm{c}$ & $285.11 \mathrm{c}$ \\
SB20\% & $130.34 \mathrm{e}$ & $5.387 \mathrm{c}$ & $3.831 \mathrm{c}$ & $283.125 \mathrm{c}$
\end{tabular}

Means of each group in columns of each treatment with similar letters are not significantly different 
Table 7. Land equivalent ratio of forage sorghum and lima bean under different planting patterns and nitrogen fertilizer

\begin{tabular}{|c|c|c|c|c|}
\hline Nitrogen fertilizer levels $\left(\mathrm{kg} \mathrm{ha}^{-1}\right)$ & Intercropping patterns & Forage sorghum & Lima bean & Total LER \\
\hline & SSSB & .84 & .19 & 1.03 \\
\hline \multirow[t]{5}{*}{$\mathrm{N}_{0}$} & SBSB & .63 & .36 & .99 \\
\hline & SBBB & .32 & .69 & 1.01 \\
\hline & SB $10 \%$ & 1.04 & .05 & 1.09 \\
\hline & SB $20 \%$ & 1.09 & .04 & 1.13 \\
\hline & SSSB & .87 & .20 & 1.07 \\
\hline \multirow[t]{6}{*}{$\mathrm{N}_{1}$} & SBSB & .63 & .38 & 1.01 \\
\hline & SBBB & .32 & .79 & 1.11 \\
\hline & SB $10 \%$ & 1.1 & .06 & 1.16 \\
\hline & SB $20 \%$ & 1.12 & .09 & 1.21 \\
\hline & SSSB & .89 & .29 & 1.18 \\
\hline & SBSB & .75 & .37 & 1.12 \\
\hline \multirow[t]{4}{*}{$\mathrm{N}_{2}$} & SBBB & .36 & .80 & 1.16 \\
\hline & SB $10 \%$ & 1.16 & .05 & 1.21 \\
\hline & SB $20 \%$ & 1.16 & .1 & 1.26 \\
\hline & SSSB & .79 & .20 & .99 \\
\hline \multirow[t]{4}{*}{$\mathrm{N}_{3}$} & SBSB & .64 & .37 & 1.01 \\
\hline & SBBB & .35 & .73 & 1.08 \\
\hline & SB $10 \%$ & .99 & .03 & 1.02 \\
\hline & SB $20 \%$ & 1.01 & .03 & 1.04 \\
\hline
\end{tabular}

Table 8. ANOVA for forage quality of sorghum

\begin{tabular}{llllllll}
\hline S.O.V & df & DMD & CP & CF & ADF & WSC & ASH \\
\hline Block & 3 & 2.80 & 4.01 & .98 & 2.49 & 3.47 & 0.18 \\
Factor A & 3 & $3.15^{\text {n.s }}$ & $47.32^{* *}$ & $1.43^{\text {n.s }}$ & $1.56^{\text {n.s }}$ & $5.28^{\text {n.s }}$ & $0.25^{\text {n.s }}$ \\
Error a & 9 & 4.85 & 1.80 & $2.01^{* *}$ & $2.64^{* *}$ & $1.46^{*}$ & 0.79 \\
Factor B & 5 & $46.69^{* *}$ & $26.40^{* *}$ & $59.90^{* *}$ & $38.41^{* *}$ & $30.23^{*}$ & $3.08^{* *}$ \\
A B $^{*}$ & 15 & $5.68^{\text {n.s }}$ & $1.10^{\text {n.s }}$ & $2.15^{\text {n.s }}$ & $2.51^{\text {n.s }}$ & $1.69^{\text {n.s }}$ & $0.43^{\text {n.s }}$ \\
Error b & 60 & 3.05 & $1.62^{2}$ & 2.009 & 2.11 & $1.37^{2}$ & 0.29 \\
Total & 95 & 563.67 & 416.98 & 477.95 & 392.95 & 298.70 & 48.14 \\
\hline
\end{tabular}

$\mathrm{N}_{0}, \mathrm{~N}_{1}, \mathrm{~N}_{2}$ and $\mathrm{N}_{3}$ represent $0,80,160$ and $240 \mathrm{kgNha}^{-1}$, respectively 
Table 9. Mean comparison of forage quality of sorghum at different row proportions

\begin{tabular}{lllllll}
\hline Row configuration & DMD \% & CP \% & CF \% & ADF \% & WSC \% & ASH \% \\
\hline SSSS & $53.08 \mathrm{c}$ & $14.88 \mathrm{c}$ & $41.22 \mathrm{a}$ & $36.60 \mathrm{a}$ & $13.59 \mathrm{~d}$ & $7.59 \mathrm{a}$ \\
SSSB & $55.09 \mathrm{~b}$ & $14.97 \mathrm{c}$ & $39.61 \mathrm{~b}$ & $33.62 \mathrm{~d}$ & $16.89 \mathrm{a}$ & $7.08 \mathrm{~b}$ \\
SBSB & $57.42 \mathrm{a}$ & $16.40 \mathrm{~b}$ & $37.53 \mathrm{c}$ & $33.94 \mathrm{~cd}$ & $15.19 \mathrm{bc}$ & $6.41 \mathrm{~d}$ \\
SBBB & $56.63 \mathrm{a}$ & $18.08 \mathrm{a}$ & $35.77 \mathrm{~d}$ & $32.17 \mathrm{e}$ & $14.47 \mathrm{c}$ & $6.44 \mathrm{~cd}$ \\
SB10\% & $53.48 \mathrm{c}$ & $14.92 \mathrm{c}$ & $39.72 \mathrm{~b}$ & $35.46 \mathrm{~b}$ & $13.10 \mathrm{~d}$ & $6.97 \mathrm{~b}$ \\
SB20\% & $54.21 \mathrm{bc}$ & $16.57 \mathrm{~b}$ & $39.61 \mathrm{~b}$ & $34.90 \mathrm{bc}$ & $15.49 \mathrm{~b}$ & $6.83 \mathrm{bc}$ \\
\hline
\end{tabular}

Values followed with the same alphabet in a column do not differ significantly

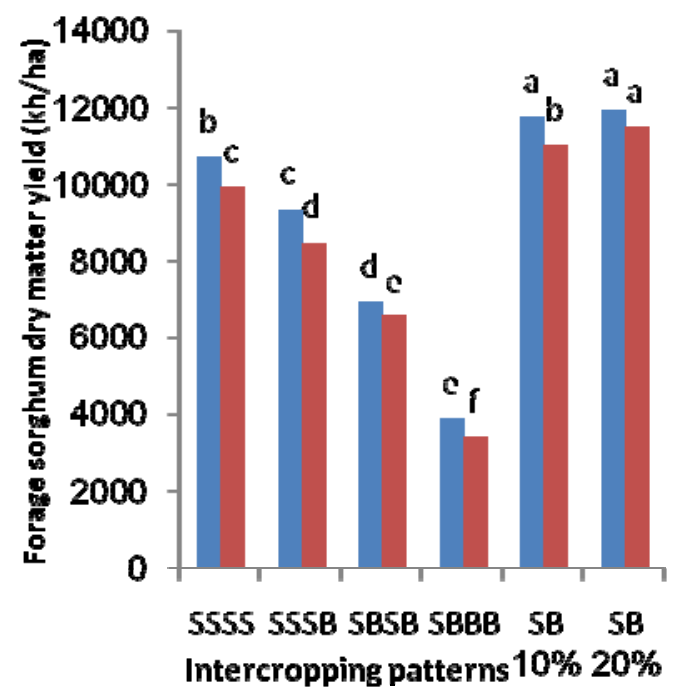

Figure 1. Dry matter yield of forage sorghum $1^{\text {st }}$ and $2^{\text {nd }}$ harverst

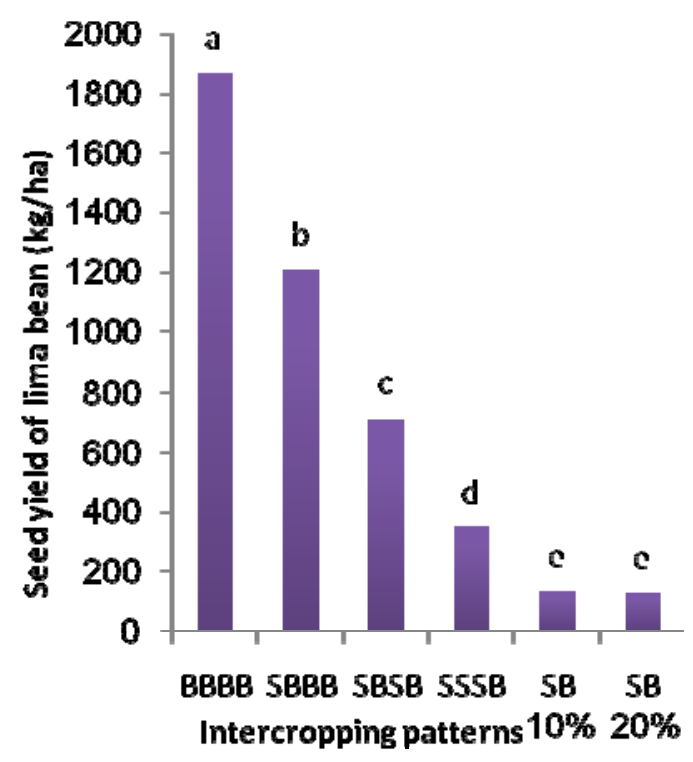

Figure 2. Yield comparison of Lima Bean under different planning patterns 


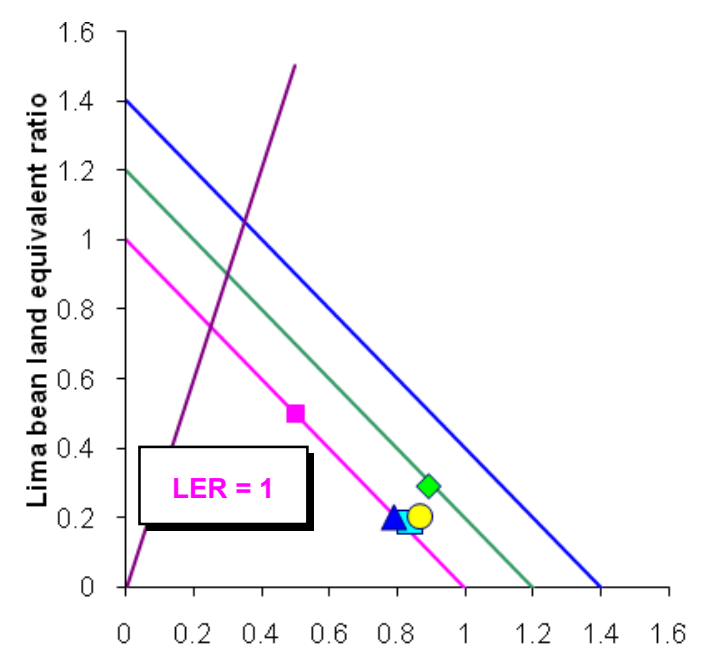

Sorghums land equivalent ratio

Figure 3. Land equivalent ratio at $75 \% \mathrm{~S}+25 \% \mathrm{~B}$
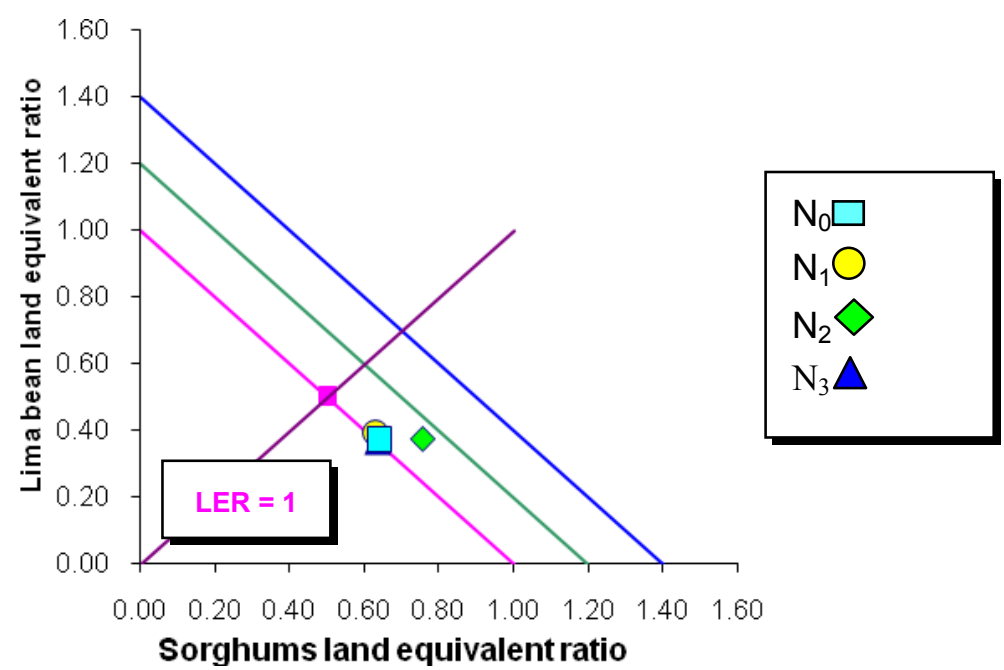

Figure 4. Land equivalent ratio at $50 \% \mathrm{~S}+50 \% \mathrm{~B}$

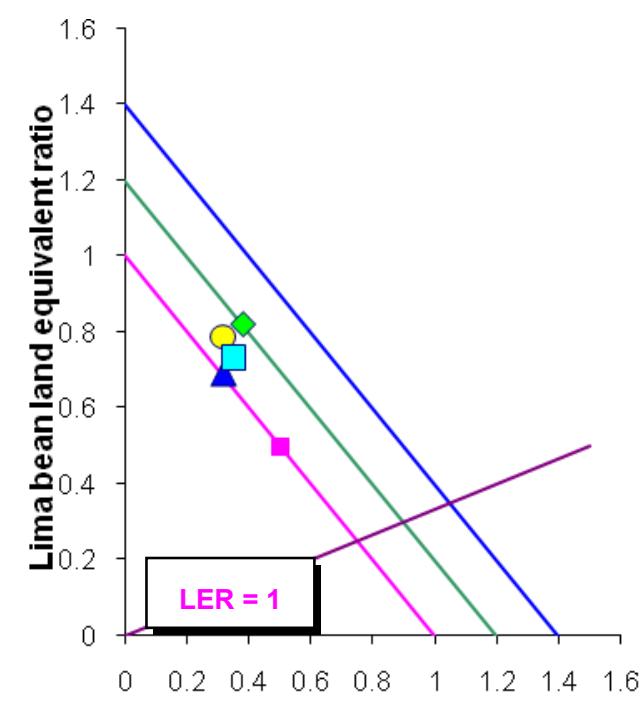

Sorghums land equivalent ratio

Figure 5. Land equivalent ratio at $25 \% \mathrm{~S}+75 \% \mathrm{~B}$ 